Ann. Biol. anim. Bioch. Biophys., 1977, 17 (4), 583-588.

\title{
Postprandial absorption of $\alpha$-aminonitrogen and sugars in pigs. Quantitative measurement using discontinuous pancreatic derivation
}

\author{
par A. RÉRAT, T. CORRING, P. VAISSADE, P. VAUGELADE \\ Laboratoire de Physiologie de la Nutrition \\ I.N.R.A., 78350 Jouy-en-Josas, France.
}

The role of the pancreas in profein digestion was investigated in the past either by digestibility or absorption studies. Partial pancreatectomy in the dog (Cohen and Annegers, 1953) or ligature of the pancreatic duct in the pig (Pekas, Hays and Thompson, 1964 ; Anderson and Ash, 1971 ; Corring and Bourdon, 1977) resulted in poor utilization of dietary protein, decrease in apparent digestibility ranging between 13 and 70 p. 100 . After total pancreatectomy in dog, nitrogen absorption decreased by 30 p. 100 one hour after a meal containing ${ }^{131}$-labelled serum albumin (Shingleton et al,, 1955 ; Douglas et al., 1953). Measurement of the $\alpha$-aminonitrogen level in the systemic plasma was used to define total pancreatic enzyme deficiencies in children (West, Wilson and Eyles, 1946 ; Anfanger and Heavenrich, 1949). However, the limits of the methods used for these studies must be examined. Only the disappear ance of dietary constituents is measured with digestibility techniques so that the kinetics of the occurrence of nutrients in the organism or the nature of these nutrients is not specified. Furthermore, $\alpha$-aminonitrogen titer in the systemic plasma hardly indicates the process of absorption because absorbed nutrients may be metabolized in the liver.

For these reasons, it seemed necessary to use more accurate criteria for estimating the role of the pancreas in the digestive processes. Thus, the absorption of a given nutrient can be quantitatively determined at any moment after the meal by simultaneously measuring the nutrient enrichment of the digestive tract efferent blood and the flow rate of the blood irrigating this organ. In other words, the amounts absorbed (q) after a determined meal and for a given time (dt) can be estimated by continuously measuring postprandial differences in porto-arterial titer $\left(C_{p}-C a\right)$ of the nutrient studied and portal flow rate $\left(F_{r}\right)$, using the formula, $q=\left(C_{p}-C a\right) F_{r} d t$. It must be emphasized that this computation does not take into account the quantities of nutrients metabolized in the gut wall; it concerns only apparent absorption. This method was used to study the effect of the presence or absence of pancreatic juice in the gut on the kinetics of absorption of $\alpha$-aminonitrogen, reducing substances and aminoacids. The results of studies in progress on the latter will not be reported here. 


\section{Material and methods.}

Nine pigs (30-50 kg liveweight) were fitted with permanent cannulae in the portal vein and the aorta (through the carotid). A flow probe connected with an electromagnetic flowmeter was placed around the portal vein (Rérat, 1971). These same animals were also fitted with pancreatic and duodenal permanent cannulae (Corring. Aumaitre and Rérat, 1972). About ten days after these had been placed, several series of assays were done on the animals (reintroduction vs no reintroduction of pancreatic juice into the gut) after intake of a given meal (table 1) varying in

TABLE 1

Cereal mixture (composition per 100)

\begin{tabular}{lc} 
Barley & 35 \\
Wheat & 15 \\
Maize & 15 \\
Wheat bran & 10 \\
Soyabean meal & 18 \\
Sodium chloride & 0.5 \\
Ground chalk & 1.2 \\
Calcium carbonate & 1.2 \\
Trace elements & 0.1 \\
Vitamin mixture & 4 \\
\hline
\end{tabular}

$N \times 6.25=16.3$

amount between $250 \mathrm{~g}$ and $700 \mathrm{~g}$. In experiments with no reintroduction, return of pancreatic juice to the gut was stopped $14 \mathrm{hrs}$ before the meal to be sure that no pancreatic enzymes were left in the gut ; this was confirmed by enzymatic determination of gut contents (Palmers and Peters, 1965). Blood levels of $\alpha$-aminonitrogen and reducing substances (Vaissade, Aumaitre and Rérat, 1973) were continuously recorded during an 8-hour postprandial period.

\section{Results.}

For studying the gross effect of exocrine pancreas on absorption, all data on the occurrence of $\alpha$-aminonitrogen and reducing substances in the portal blood during an 8-hr post-prandial period were related to protein and carbohydrate intake, levels, respectively (table 2).

When the pancreatic juice was returned to the gut, there was a close linear relationship between absorbed $\alpha$-aminonitrogen and protein intake ; the correlation coefficient, $r=0.88$, was highly significant. The value of the ordinate at the origin (for zero protein intake) is of special interest ; this $20 \mathrm{~g}$ value, representing the absorbed $\alpha$-aminonitrogen of endogenous origin, was very close to the data directly recorded with a protein-free diet $(16.3 \mathrm{~g}$ for a postprandial period of $7 \mathrm{hrs}$ : Rérat, Corring and Laplace, 1976). When no pancreatic juice was reintroduced, the relationship between absorption and ingestion level was not so close, and the 0.56 correlation coefficient 
only significant at the 0.05 level. When comparing the two regressions, it was seen that derivation of pancreatic enzymes resulted in marked impairment of nitrogen absorption, i. e. about a 40 p. 100 reduction for a $100 \mathrm{~g}$ protein meal. When consider-

TABLE 2

Relationship between the amount absorbed $(\mathrm{Y} g)$ after $8 \mathrm{~h}$ and the amount ingested $(\mathrm{Xg})$

\begin{tabular}{|c|c|c|c|c|}
\hline & $n$ & Regression & $r$ & Significance \\
\hline \multicolumn{5}{|l|}{$\alpha$-aminonitrogen } \\
\hline $\begin{array}{l}\text { With pancreatic juice } \ldots \ldots \ldots \ldots \ldots \ldots \\
\text { Without pancreatic juice } \ldots \ldots \ldots \ldots \ldots\end{array}$ & $\begin{array}{l}14 \\
11\end{array}$ & $\begin{array}{l}Y=0.64 X+20 \\
Y=0.31 X+21\end{array}$ & $\begin{array}{l}0,887 \\
0.561\end{array}$ & $\stackrel{* *}{*}$ \\
\hline \multicolumn{5}{|l|}{ Reducing sugars } \\
\hline $\begin{array}{l}\text { With pancreatic juice } \ldots \ldots \ldots \ldots \ldots \ldots \\
\text { Without pancreatic juice } \ldots \ldots \ldots \ldots \ldots \ldots\end{array}$ & $\begin{array}{r}10 \\
9\end{array}$ & $\begin{array}{l}Y=0.42 X-10 \\
Y=0.13 X+80\end{array}$ & $\begin{array}{l}0.774 \\
0.215\end{array}$ & $\stackrel{*}{N S}$ \\
\hline
\end{tabular}

ing the mean data of apparent absorption during an 8-hr postprandial period (table 3), this difference was not apparent for the lowest intake levels $(\sim 40 \mathrm{~g})$, absorption percentage being almost the same in the two conditions (with vs without pancreatic juice). However, this difference was evident for the highest quantities ingested (41 p. 100 reduction for $80 \mathrm{~g}$ intake, $35 \mathrm{p} .100$ reduction for $112 \mathrm{~g}$ intake). It must be noted at the highest levels of intake that, in the absence of pancreatic enzymes, the quantities

TABLE 3

Apparent absorption (during a postprandial period of $8 \mathrm{hrs}$ ) of sugars dan aminoacids ; variations with level of ingestion

\begin{tabular}{|c|c|c|c|c|c|c|c|}
\hline & \multirow{3}{*}{$\begin{array}{l}\text { Ingested } \\
\text { quantity } \\
\text { (g) }\end{array}$} & \multicolumn{3}{|c|}{ With pancreatic juice } & \multicolumn{3}{|c|}{ Without pancreatic juice } \\
\hline & & \multirow{2}{*}{$n$} & \multicolumn{2}{|c|}{ Absorption } & \multirow{2}{*}{$n$} & \multicolumn{2}{|c|}{ Absorption } \\
\hline & & & $\begin{array}{l}\text { Quantity } \\
\text { (g) }\end{array}$ & p. 100 & & $\begin{array}{l}\text { Quantity } \\
\text { (g) }\end{array}$ & p. 100 \\
\hline $\begin{array}{l}\text { Reducing ....... } \\
\text { Substances } \ldots .\end{array}$ & $\begin{array}{l}365 \\
511\end{array}$ & $\begin{array}{l}4 \\
4\end{array}$ & $\begin{array}{l}136 \pm 8.1 \\
202 \pm 32.2\end{array}$ & $\begin{array}{l}37.2 \pm 2.2 \\
40.5 \pm 5.0\end{array}$ & $\begin{array}{l}4 \\
4\end{array}$ & $\begin{array}{l}117 \pm 21.6 \\
155 \pm 53.5\end{array}$ & $\begin{array}{l}32,1 \pm 5.9 \\
30.4 \pm 10.5\end{array}$ \\
\hline $\begin{array}{c}\text { Free amino } \ldots . \\
\text { acids } \ldots . . .\end{array}$ & $\begin{array}{c}\sim 40 * \\
80 \\
112\end{array}$ & $\begin{array}{l}3 \\
4 \\
5\end{array}$ & $\begin{array}{l}42,7 \\
72.5 \pm 3.1 \\
90.3 \pm 5.9\end{array}$ & $\begin{array}{r}100.5 \\
90.6 \pm 3.9 \\
80.7 \pm 5.3\end{array}$ & $\begin{array}{l}2 \\
4 \\
4\end{array}$ & $\begin{array}{l}37.0 \\
42.7 \pm 7.8 \\
58.3 \pm 8.3\end{array}$ & $\begin{array}{l}99.2 \\
53.3 \pm 9.8 \\
52.1 \pm 7.4\end{array}$ \\
\hline
\end{tabular}

* mean : with pancreatic juice : $42.6 \mathrm{~g}$. without - - : $37.6 \mathrm{~g}$. 
absorbed increased at the same rate as the intake level, the percentage of absorption (53 p. 100), however, being far below that observed in normal conditions ( 80 to 90 p. 100). All these data indicated that the impairment of nitrogen digestion due to absence of pancreatic enzymes was more marked for high intakes than for low quantities. The problem of absorption of very high quantities must therefore be studied in more detail.

The evolution of the process of absorption (expressed as hourly quantities during the course of digestion) (table 4) showed that reduction of absorption, only evident

TABLE 4

Evolution of the mean absorption of $\alpha$-aminonitrogen per time unit ( $g /$ hour $)$ during the post-prandial period

\begin{tabular}{|c|c|c|c|c|c|c|c|}
\hline \multicolumn{3}{|c|}{ Time interval after the meal $(h)$} & \multirow[t]{2}{*}{$0-2$} & \multirow[t]{2}{*}{$2-4$} & \multirow[t]{2}{*}{ 4-6 } & \multirow[t]{2}{*}{$6-8$} & \multirow[t]{2}{*}{$\overline{\mathbf{m}}$} \\
\hline $\begin{array}{l}\text { Amount } \\
\text { of protein } \\
\text { ingested }\end{array}$ & $\begin{array}{l}\text { Pancreatic } \\
\text { juice }\end{array}$ & $\begin{array}{l}\text { Number } \\
\text { of data }\end{array}$ & & & & & \\
\hline $40(\sim)$ & + & $\begin{array}{l}(3) \\
(2)\end{array}$ & $\begin{array}{l}7.5 \\
6.3\end{array}$ & $\begin{array}{l}5.9 \\
5.8\end{array}$ & $\begin{array}{l}3.8 \\
3.3\end{array}$ & $\begin{array}{l}4.2 \\
3.3\end{array}$ & $\begin{array}{l}5.4 \\
4.8\end{array}$ \\
\hline 60 & \pm & $\begin{array}{l}(2) \\
(1)\end{array}$ & $\begin{array}{r}10.3 \\
5.0\end{array}$ & $\begin{array}{r}10.1 \\
6.5\end{array}$ & $\begin{array}{l}7.3 \\
4.4\end{array}$ & $\begin{array}{l}5.3 \\
2.3\end{array}$ & $\begin{array}{l}8.3 \\
4.6\end{array}$ \\
\hline 80 & $\stackrel{+}{-}$ & $\begin{array}{l}(4) \\
(4)\end{array}$ & $\begin{array}{l}9.5 \\
4.8\end{array}$ & $\begin{array}{r}10.1 \\
5.8\end{array}$ & $\begin{array}{l}8.7 \\
6.3\end{array}$ & $\begin{array}{l}7.9 \\
4.5\end{array}$ & $\begin{array}{l}9.1 \\
5.3\end{array}$ \\
\hline 112 & + & $\begin{array}{l}(5) \\
(4)\end{array}$ & $\begin{array}{l}9.8 \\
6.0\end{array}$ & $\begin{array}{r}13.7 \\
9.7\end{array}$ & $\begin{array}{r}11.3 \\
7.4\end{array}$ & $\begin{array}{r}10.2 \\
6.0\end{array}$ & $\begin{array}{r}11.3 \\
7.3\end{array}$ \\
\hline $\begin{array}{l}\bar{m}=80,6 \\
\bar{m}=82,0\end{array}$ & \pm & $\begin{array}{l}(14) \\
(11)\end{array}$ & $\begin{array}{l}9,3 \\
5.5\end{array}$ & $\begin{array}{r}10.5 \\
7.3\end{array}$ & $\begin{array}{l}8.4 \\
6.0\end{array}$ & $\begin{array}{l}7.6 \\
4.6\end{array}$ & $\begin{array}{l}8.95 \\
5.86\end{array}$ \\
\hline \multicolumn{3}{|c|}{ Statistical significance $\left(^{(}\right)$} & & & & & $\begin{array}{l}\text { Degree of } \\
\text { freedom }\end{array}$ \\
\hline \multicolumn{3}{|c|}{$\begin{array}{l}\text { Pancreatic juice }(+ \text { or }-) \ldots \ldots \ldots \ldots \\
\text { Amount of protein ingested } \ldots \ldots \ldots \ldots \\
\text { Interaction } \ldots \ldots \ldots \ldots \ldots \ldots \ldots\end{array}$} & $\begin{array}{r}12.41 * * \\
0.34 \mathrm{NS} \\
0.60 \mathrm{NS}\end{array}$ & $\begin{array}{c}11.13 * * \\
7.82 * * \\
0.88 \mathrm{NS}\end{array}$ & $\begin{array}{l}6.57 * \\
6,39 * * \\
0.47 \text { NS }\end{array}$ & $\begin{array}{l}8.19 * \\
3.93 * * \\
0.39 \mathrm{NS}\end{array}$ & $\begin{array}{l}\text { (1) } \\
\text { (3) } \\
\text { (3) }\end{array}$ \\
\hline
\end{tabular}

(1) Value of $F$.

* Significant at the 0.05 level.

** Significant at the 0.01 level.

NS Non Significant.

over and from $60 \mathrm{~g}$ of protein intake, occurred very early when the pancreatic juice was not returned; the relative magnitude of the decrease caused by absence of pancreatic enzymes seemed fairly constant during the whole digestive process, whatever the protein intake. It is to be wondered what happens after the end of the: study period; it is most likely that digestive and absorptive processes continue during; a longer period when pancreatic secretions are absent than when they are present. Despite the decreasing hourly quantities absorbed, the drop in nitrogen digestibility 
was no more than 13 p. 100 when pancreatic juice was derived by cannulation (Corring and Bourdon, 1976). This decrease in digestibility was, however, about 35 p. 100 over a longer period when the pancreatic duct was ligated (Corring and Bourdon, 1977).

As regards apparent absorption of sugars, when the pancreatic juice was returned to the gut, there was a linear relationship between occurrence of reducing substances (expressed as cumulated amounts absorbed during an 8-hour postprandial period) and quantity of dietary carbohydrates (table 2); the correlation coefficient $(r=0.77)$ was significant at the 0.02 level. The slope of this line was close to that previously noted for animals without any pancreatic and duodenal cannulae and fed maize starch diets (Réraf and Aumaitre, 1975 ; Rérat ef al., 1976). When the pancreatic juice was not returned, there was no relationship between absorption and intake level because of the great dispersion of data. However, means recorded at two intake levels (table 3 ) showed that absence of pancreatic enzymes resulted in about a 20 p. 100 depression of carbohydrate absorption rate for $8 \mathrm{hrs}$. Comparison of this result with digestibility data (Corring and Bourdon, 1976) shows there is a compensatory effect during late digestion, the differences in absorption between the two assays (with vs without pancreatic juice) disappearing when digestibility is examined.

These preliminary results show that absence of pancreatic enzymes results in early depression of the absorption of protein and carbohydrate digestive products. Decreased carbohydrate absorption, due to absence of amylolytic enzymes, is less than depressed nitrogen absorption because of absence of proteolytic enzymes. However, this early depression does not necessarily result in a drop in digestibility of the same magnitude, and must be considered in relation to its effects on the duration of digestion, pattern of absorption products (particularly aminoacids) and their metabolic utilization.

Commission CNERNA Digestion-Absorption, Tours, 13 novembre 1976.

Résumé. Le rôle du pancréas exocrine dans la digestion des protéines et des glucides a été examiné à l'aide d'une méthode directe permettant de rendre compte à la fois de la cinétique de l'absorption et de la nature des nutriments absorbés. Dans ce but on mesure simultanément, de façon continue, l'enrichissement postiprandial en nutriments (azote $\alpha$ aminé et sucres réducteurs) du sang efférent du tube digestif, et le débit $D$ du sang irriguant cet organe, les quantités $(q)$ absorbées étant calculées grâce à la formule $q=(C p-C a) D d t$, où $C p$ et Ca représentent les concentrations instantanées des nutriments étudiés dans la veine porte et l'artère aorte, et dt le temps d'étude $(8 \mathrm{~h})$. Neuf porcs (30-50 kg de poids vif) munis de cathéters permanents de la veine porte et de l'artère aorte, d'une sonde débitmétrique autour de la veine porte ainsi que de canules permanentes du canal pancréatique et du duodénum sont soumis à plusieurs séries d'essais (réintroduction ou non réintroduction du suc pancréatique dans le tube digestif au cours de la digestion), réalisés aprés l'ingestion d'un repas défini. Dans ces conditions, l'absence de suc pancréatique se traduit très précocement par un ralentissement marqué de l'absorption d'azote $\alpha$-aminé, les quantités apparues dans l'organisme pendant $8 \mathrm{~h}$ étant environ 40 p. 100 inférieures à celles trouvées en présence du suc pancréatique. Ce phénomène semble varier selon le niveau de consommation. L'absorption apparente des sucres est sensiblement moins affectée que celle des protéines, la dépression liée à l'absence de suc pancréatique étant environ de 20 p. 100. 


\section{Références}

ANDERSON D. M., ASH R. W., 1971. The effect of ligating the pancreatic duct on digestion in the pig. Proc. Nutr. Soc., 30, 34A-35A.

ANFANGER H., HEAVENRICH R. M. C., 1949. Aminoacid tolerance test in children. Am. J. Dis. Child., 77, 425-436.

COHEN B. J., ANNEGERS J. M., 1953. Fecal loss of various dietary nutrients in dogs lacking pancreatic juice. Gastroenterology, 25, 67-71.

CORRING T., AUMAITRE A., RERAT A., 1972. Fistulation permanente du pancréas exocrine chez le porc. Application : réponse de la sécrétion pancréatique au repas. Ann. Biol. anim. Bioch. Biophys., 12, 109-124.

CORRING T., BOURDON D., 1976. Short-dated influence of removal of the exocrine pancreatic secretion (enzymatic or total) upon the apparent digestibility of a diet in the pig. Nutr. Rep. Int., 14, 621-627.

CORRING T., BOURDON D., 1977. Effets à long terme de la ligature du canal pancréatique sur la digestibilité apparente chez le porc. Commission «Physiologie et Biochimie normale et pathologique de la digestion et de l'absorption ». C.N.E.R.N.A. (Tours). Ann. Biol. anim. Bioch. Biophys. 17, 579-582.

DOUGLAS G. J., REINAUER A. J., BROOKS W. C., PRATT J. H., 1953. The effect on digestion and absorption of excluding the pancreatic juice from the infestine. Gastroenterology, 23, 452-459.

PALMERS D. W., PETERS T. Jr., 1965. Simple automatic determination of aminogroups in serum/plasma using trinitrobenzene sulfonate. In Automation in Analytical Chemistry, Technicon Symposia, P. 324.

PEKAS J. C., HAYS V. W., THOMPSON A. M., 1964. Exclusion of the exocrine pancreatic secretion. Effect on digestibility of soybean and milk protein by baby pigs at various ages. J. Nutr., 82, 277-286.

RÉRAT A., 1971. Mesure du débit du sang dans la veine porte à l'aide d'un débitmètre électromagnétique chez le porc. Ann. Biol. anim. Bioch. Biophys., 11, 175-180.

RÉRAT A., AUMAITRE A., 1975. Quantitative measurement of the absorption of various polysac charides by studying the porto-arterial differences and the portal blood flow rate in the pig $20^{\circ}$ Congr. Mond. Vét., Thessalonique, vol. 125 (ASL).

RÉRAT A., AUMAITRE A., VAISSADE P., VAUGELADE P., 1976. Absorption of digestion products of some holosides : quantitative measurement by studying the portoarterial differences and the portal blood flow rate in the pigs. Int. Pig Vet. Soc., Ames (lowa), U.S.A., Proc. 4th Intern. Congress, A 12.

RÉRAT A., CORRING T., LAPLACE J. P., 1976. Protein digestion and absorption. In COLE D. J. A., BOORMAN K. N., BUTTERY P. J., LEWIS D., NEALE R. J., SWAN H., Protein metabolism and nutrition, E.A.A.P., publ. 16, 97-138, Butterworths, N. Y., London.

SHINGLETON W. W., WELLS M. H., BAYLIN G. H., RUFFIN J. M., SAUNDERS A., DURHAM N. C., 1955. The use of radioactive labelled protein and fat in the evaluation of pancreatic disorders. Surgery, 38, 134-142.

VAISSADE P., AUMAITRE A., RÉRAT A., 1973. Mesure en continu de la glycémie des sangs porte et périphérique chez le porc éveillé : application à l'étude de l'absorption intestinale des glucides. Symp. Inter. Pharm. Technicon, Paris, 4-5 oct. 1973, 18 pp.

WEST D. D., WILSON J. L., EYLES R., 1946. Blood amino nitrogen levels. Changes in blood amino nitrogen levels following ingestion of proteins and of a protein hydrolysate function. Am. J. Dis. Child., 72, 251. 